\title{
High efficiency of calcined anionic clay to remove the chromate anions $\mathrm{CrO}_{4}{ }^{2-}$
}

\section{from polluted water}

\author{
El Hassane Mourid, Mohamed Lakraimi*, Lhaj Benaziz \\ Physical Chemistry of Materials Team, Cadi Ayyad University, Marrakech, Morocco \\ mlakraimi@yahoo.fr
}

Keywords: calcined anionic clay, anions $\mathrm{CrO}_{4}{ }^{2-}$, elimination, intercalation, regeneration.

Calcined anionic clay based on zinc and aluminum was used to remove the pollutant $\mathrm{CrO}_{4}{ }^{2-}$ from wastewater. This adsorbent material derived from layered double hydroxide (LDH) was chosen for its higher adsorption capacity, its affinity for most pollutants, and its non-toxicity. The kinetic study suggesting a high affinity between the pollutant and calcined LDH (CLDH). The pollutant is retained in multilayer and follows the Freundlich model. Thermodynamic study indicates a physical interaction. The elimination reaches $100 \%$ with a retention capacity of $3333 \mathrm{mg} / \mathrm{g}$. After cycles of regeneration and in comparison with other adsorbents, CLDH has proven its efficiency and high performances to remove $\mathrm{CrO}_{4}{ }^{2-}$ anions.

\section{Introduction}

Wastewater pollution represents one of the most worrying aspects of the global environmental crisis, and is currently of particular importance at international level [1]. Among the toxic pollutants, chromium compounds have been the subject of much research and attention in recent years $[2,3]$. The main human activities that increase the chromium concentrations in water are the manufacture of chromed steel, chromium as an additive in alloys or as a dye and mordant in dyeing, the rejects of electroplating workshops, the products of wood preservation, etc. [4,5]. Its toxicity depends on the oxidation degree.
Trivalent and hexavalent chromium are the two stable forms. The latter is more toxic than the first one because it is very soluble and can be accumulated by absorption in the body over biological films, especially in the stomach and kidneys. It can be bioaccumulated by various organisms, including plants, through contaminated irrigation water. In these cases, it can become one of the food contaminants that can affect human health $[6,7]$. For these reasons, its removal from wastewater seems necessary to reduce its harmful impact on the ecosystem in general. The limit value of hexavalent chromium authorized in water is around $0.051 \mathrm{mg} / \mathrm{L}[8,9]$. $\mathrm{Cr}(\mathrm{VI})$ is considered one of the pollutants which 
are mutagenic and carcinogenic [10,11], it also causes cutaneous and respiratory hypersensitivity [12]. In addition to its toxicity, $\mathrm{Cr}(\mathrm{VI})$ causes a threat to surface water and groundwater due to its high mobility in most neutral and alkaline soils [13].

There are many conventional techniques for treating effluents contaminated with chromium; these include membrane filtration, precipitation, ionic exchange and adsorption. The use of membranes and ionic exchange are effective methods of elimination, but they remain expensive and therefore not very applicable to the production of drinking water. Adsorption is a simple, effective, economical method and remains the most used for the retention of wastewater pollutants [14-16]. The elimination of this heavy metal by adsorption has been the thing of several studies [17-22].

The goal of this work is to assess the elimination capacity of $\mathrm{CrO}_{4}{ }^{2-}$ by adsorption on calcined anionic clay based on zinc and aluminum. The study includes the influence of several parameters on the elimination rate, such as the contact time adsorbate-adsorbent, the medium $\mathrm{pH}$, the material mass, the chromate anions concentration and temperature.

\section{Experimental part}

\section{Adsorbent preparation}

The hydrotalcite material $\mathrm{Zn}-\mathrm{Al}$ intercalated by carbonate anions was synthetized by coprecipitaion method at $\mathrm{pH} 10$ from a mixture of metal salts $\left(\mathrm{ZnCl}_{2}\right) 0.5 \mathrm{M}$ and $\left(\mathrm{AlCl}_{3}\right)$ $0.5 \mathrm{M}$ with a metal ratio $\mathrm{Zn} / \mathrm{Al}=2$. The $\mathrm{pH}$ was maintained at 10 by adding a solution of basic anions containing $0.75 \mathrm{M} \mathrm{Na}_{2} \mathrm{CO}_{3}$ and $0.25 \mathrm{M}$ of $\mathrm{NaOH}$. At the end of the precipitation reaction, a maturation time of 72 hours with moderate stirring was adopted, and then the hydrotalcite material obtained was calcined at $500{ }^{\circ} \mathrm{C}$ for 5 hours.

\section{Adsorption experiments}

Retention at different time was conducted by batch tests. The mixtures were prepared by dispersing an amount of CLDH (30, 50 or $80 \mathrm{mg})$ in $100 \mathrm{~mL}$ of $\mathrm{Cr}(\mathrm{VI})$ solutions at different concentrations, varying from 40 to $800 \mathrm{mg} / \mathrm{L}$. The $\mathrm{pH}$ was kept constant by adding dilute solutions of $\mathrm{HCl}(0.1 \mathrm{M})$ or $\mathrm{NaOH}(0.1 \mathrm{M})$. After retention, the adsorbent material was separated by filtration and analyzed by XRD, IR, TGA/DTG, and SEM/EDS. The filtrate was analyzed by UV-Vis for determining the residual concentration of $\mathrm{Cr}(\mathrm{VI})$. The retention capacity was assessed using Eq. (1):

$\mathrm{Q}=\left(\mathrm{C}_{\mathrm{i}}-\mathrm{C}_{\mathrm{e}}\right) \times \mathrm{V} / \mathrm{m}$

Where $\mathrm{Q}$ represents the quantity of $\mathrm{Cr}(\mathrm{VI})$ retained by mass of CLDH $(\mathrm{m})$ in the volume $\mathrm{V}$. $\mathrm{C}_{\mathrm{i}}$ and $\mathrm{C}_{\mathrm{e}}$ represent the pollutant concentrations before contact and after equilibrium.

\section{Quantification of chromate anions $\left(\mathrm{CrO}_{4}{ }^{2-}\right)$}

UV-Vis spectrophotometry assay method was exploited to identify the concentration of this pollutant by adding the reactive 1,5- 
diphenylcarbazide (DPC) in the solution, this technique is only applicable in a strongly acidic medium. The $\mathrm{Cr}(\mathrm{VI})$ analysis protocol is detailed by Dedkova et al. [23]. In this medium, hexavalent chromium reacts completely with DPC (Figure 1a) to form a purple complex (Figure 1b) [24]. This complex can be quantified at a wavelength of $540 \mathrm{~nm}$.

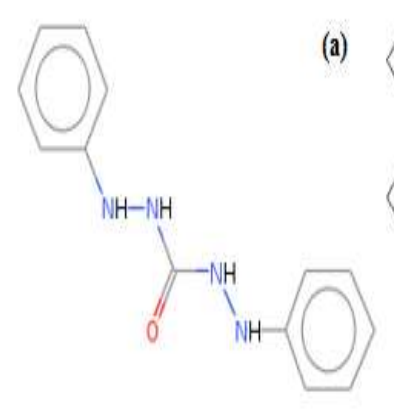

(a)

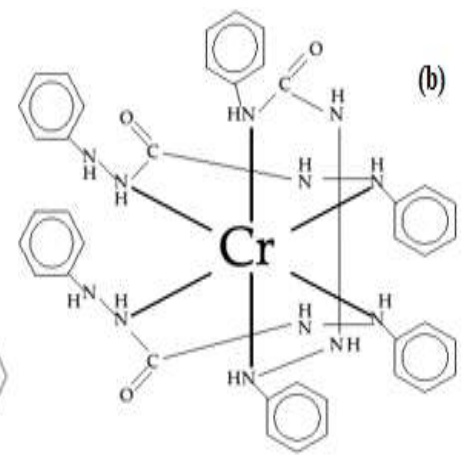

Figure 1. Structure of DPC (a) and Cr(VI) complexed by DPC (b).

\section{Characterization techniques}

After retention process of $\mathrm{Cr}(\mathrm{VI})$, the residual concentration was determined by UVVis spectrophotometer (JENWAY-6300) and the solid was characterized by infrared spectroscopy (JASCO model FT/IR-4600, $4 \mathrm{~cm}^{-1}$ of resolution and 20 is a number of scans), scanning electron microscopy with electron dispersive spectroscopy (TESCAN Vega 3 LM, accelerating voltage of $10 \mathrm{kV}$ ), X-ray diffraction (XPERT-PRO powder diffractometer, copper $\mathrm{K}_{\alpha}$ radiation, measurement conditions were $2 \mathrm{~h}$ range 5-70 ${ }^{\circ}$, step size: $0.08-2 \mathrm{~h}$, and step counting time: $4 \mathrm{~s})$ and thermogravimetric analysis TGA/DTG (Setaram, heating rate of $5{ }^{\circ} \mathrm{C} / \mathrm{min}$ ).

\section{Results and discussion}

XRD characterization of the adsorbent

XRD technique offers clues on the obtained phase (Figure 2). The LDH material corresponds to a well-crystallized compound, intercalated by carbonate anions. The corresponding interlamellar distance is of the order of $0.763 \mathrm{~nm}$ with a space group $\mathrm{R} \overline{3} \mathrm{~m}$.

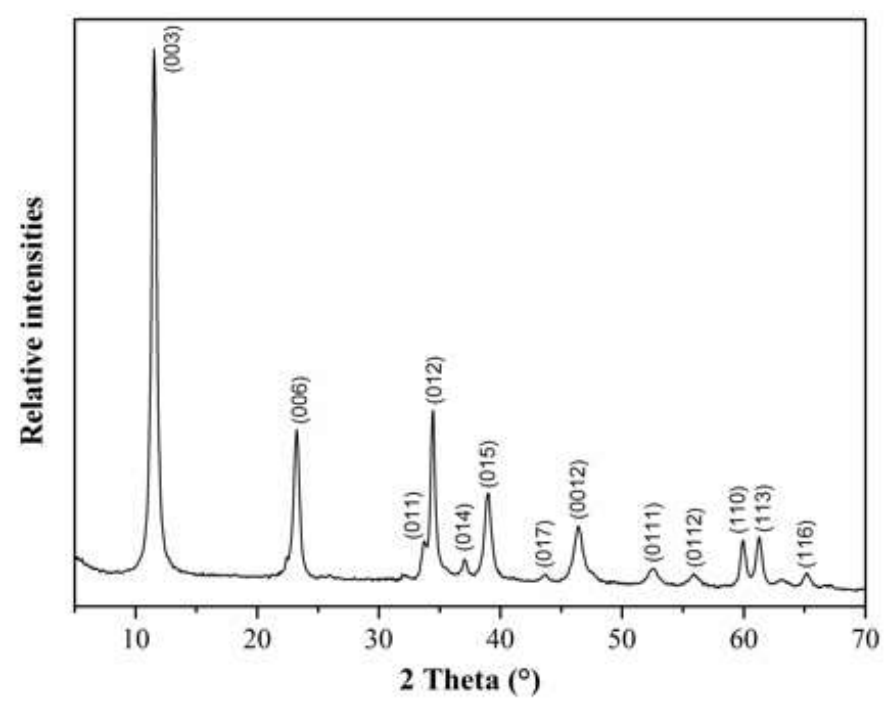

Figure 2. X-ray pattern of LDH phase $\left[\mathrm{Zn}_{2}-\mathrm{Al}-\mathrm{CO}_{3}\right]$.

\section{Effect of $p H$}

To study the influence of $\mathrm{pH}$ on chromium adsorption by CLDH, an initial concentration of $\mathrm{Cr}(\mathrm{VI})$ equal to $50 \mathrm{mg} / \mathrm{L}$ and a quantity of CLDH adsorbent of $50 \mathrm{mg}$ was used for a $\mathrm{pH}$ range varying from 4 to 11 . The $\mathrm{CLDH}-$ $\mathrm{Cr}(\mathrm{VI})$ contact time was fixed at $3 \mathrm{~h}$ for each solution at fixed $\mathrm{pH}$. After filtration, $2.5 \mathrm{~mL}$ of the DPC solution was added to the filtrate. After the formation of the complex, the absorbances were determined. The evolution of the hexavalent chromium retention versus $\mathrm{pH}$ is represented in Figure 3a. 

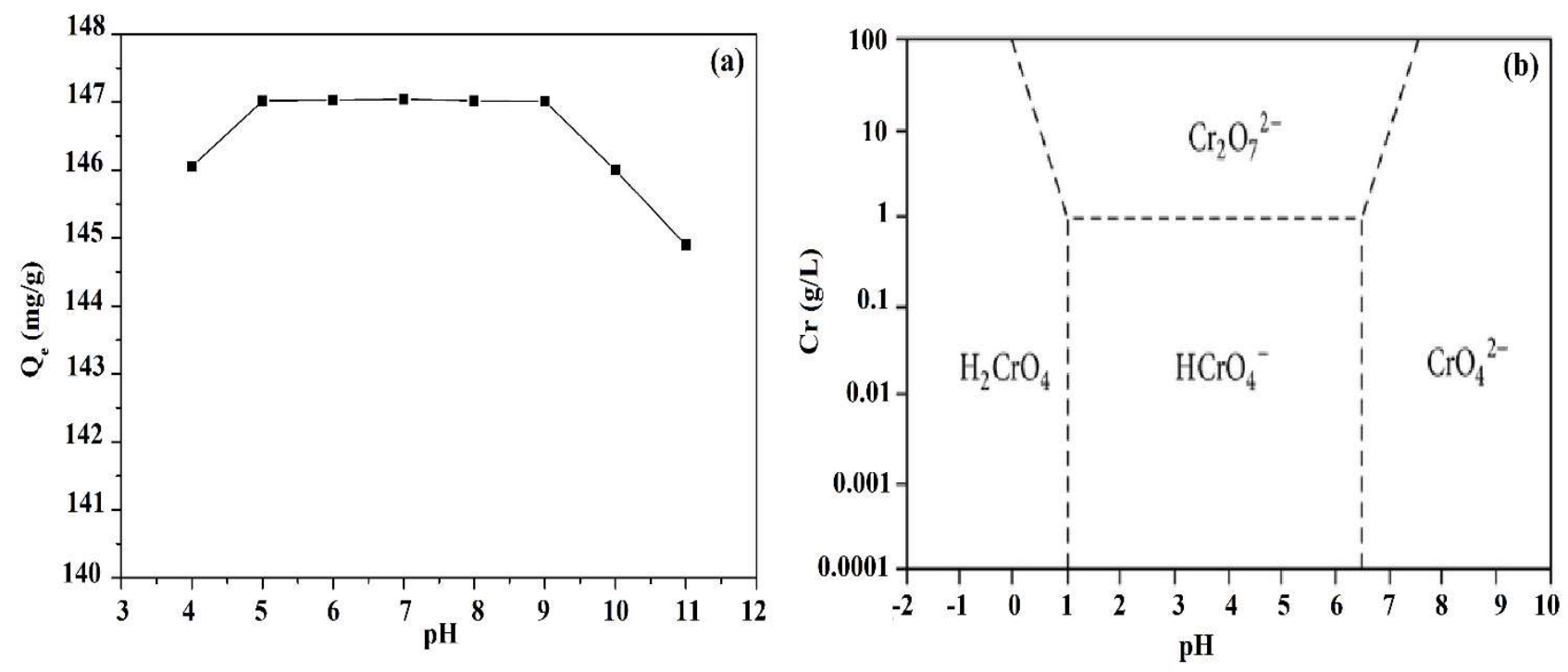

Figure 3. Evolution of the adsorbed amount of $\mathrm{Cr}(\mathrm{VI})$ at different $\mathrm{pH}$ (a) and speciation diagram of chromium (b).

The results of Figure $3 a$ have shown that the maximum retention reaches $147 \mathrm{mg} / \mathrm{g}$ for a $\mathrm{pH}$ value between 5 and 9. At this $\mathrm{pH}$ range and with the concentration used, the chromium retention mechanism can be done under two anionic forms, $\mathrm{HCrO}_{4}{ }^{-}$and $\mathrm{CrO}_{4}{ }^{2-}$. The diagram of the distribution of the different chromic species with respect to the concentration as a function of the $\mathrm{pH}$ is given in Figure $3 \mathrm{~b}$ [25]. Hexavalent chromium is mainly found in natural waters in the form of $\mathrm{H}_{2} \mathrm{CrO}_{4}$, which dissociates in ionic forms $\mathrm{CrO}_{4}{ }^{2-}$ and $\mathrm{HCrO}_{4}{ }^{-}$. When the $\mathrm{pH}$ is equal to 4 , the decrease in the retained quantity can be caused by hydrolysis of the adsorbent material [26]. The relative and a gradual decrease in the adsorption capacity of $\mathrm{CLDH}$ at $\mathrm{pH}>9$ could be probably the result of the chromate anions competition with carbonate anions [27].
The following adsorption experiments will be done at $\mathrm{pH} 7$ close to that of natural water where the $\mathrm{Cr}(\mathrm{VI})$ is under anionic form $\mathrm{CrO}_{4}{ }^{2-}$.

\section{Effect of contact time}

Adsorption kinetics is known to be one of the major parameters that determine the retention capacity. For the establishment of the adsorption equilibrium, we followed over time, the variation of the adsorbed quantity. For this, $50 \mathrm{mg}$ of CLDH was brought into contact with $100 \mathrm{~mL}$ of $\mathrm{Cr}(\mathrm{VI})$ solutions at initial concentrations of 50 , 200 and $800 \mathrm{mg} / \mathrm{L}$. The solution stirred magnetically at $25^{\circ} \mathrm{C}$ with varying times of 5 to $210 \mathrm{~min}$. The curves representing the evolution of the adsorption potential of chromium versus time are exposed in Figure 4a.

To follow the kinetics parameters, several linearized models are established: 
The linearization of the first kinetic model is and $\mathrm{k}_{2}$ : the rate constant $(\mathrm{g} / \mathrm{mg} / \mathrm{min})$ of the presented by Eq. (2), for the second model is written in Eq. (3) [28]:

pseudo-second order model.

$\log \left(Q_{e}-Q_{t}\right)=\log \left(Q_{e}\right)-k_{1} t$

$\mathrm{t} / \mathrm{Q}_{\mathrm{t}}=1 / \mathrm{k}_{2} \mathrm{Q}^{2}+\mathrm{t} / \mathrm{Q}_{\mathrm{e}}$

With $\mathrm{Q}_{e}$, the retained quantity at equilibrium $(\mathrm{mg} / \mathrm{g}), \mathrm{Q}_{\mathrm{t}}$, the quantity retained at time $\mathrm{t}, \mathrm{k}_{1}$ : the pseudo-first order model rate constant $\left(\mathrm{min}^{-1}\right)$,
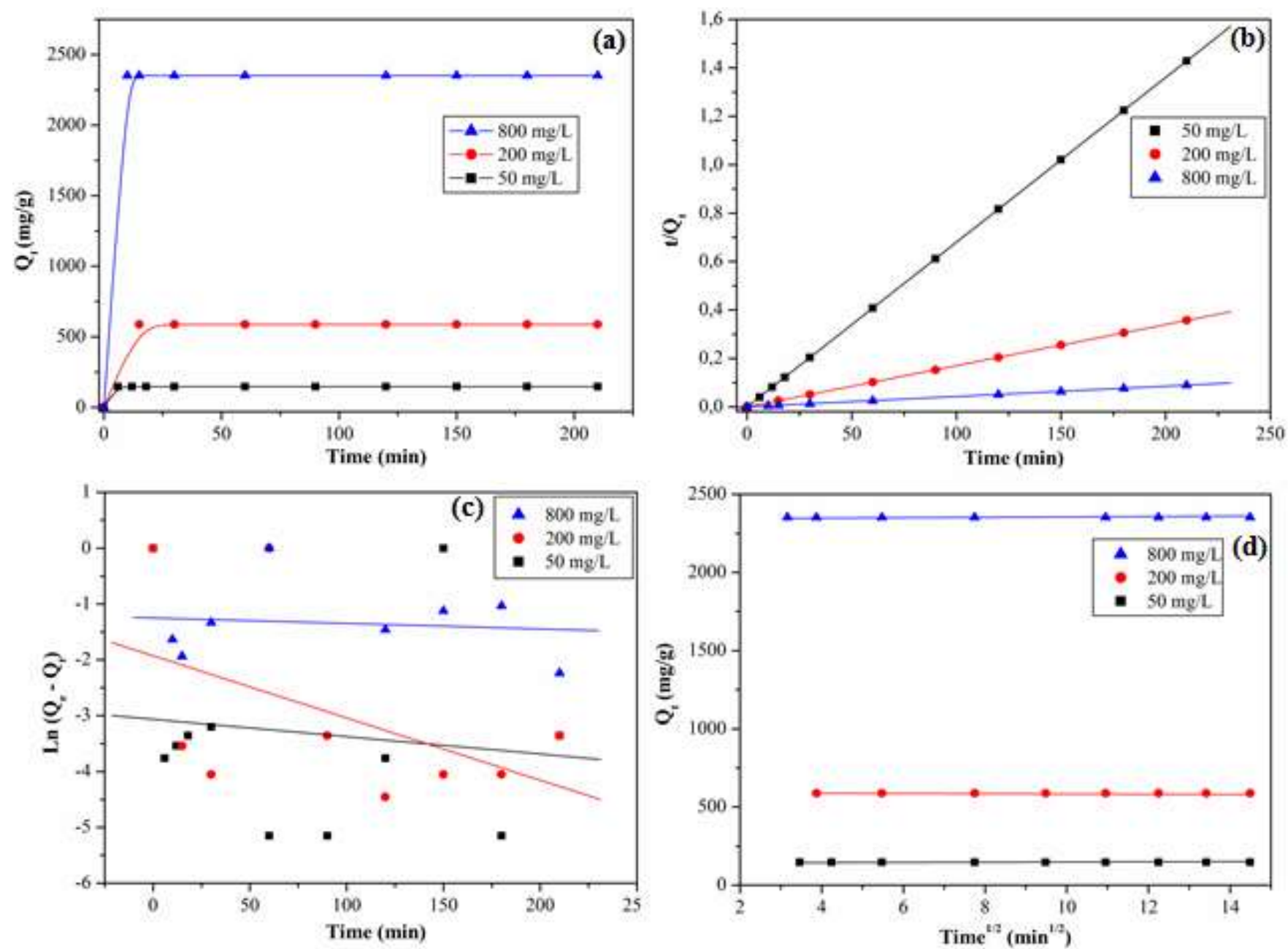

Figure $4 \mathrm{a}$ shows that the retention kinetics of $\mathrm{Cr}(\mathrm{VI})$ on CLDH is very fast. The parameters are listed in Table 1 ; the $\mathrm{R}^{2}$ values corresponding to the pseudo-first order model are so far from unity, which confirms that the kinetic process is well described by the pseudo-second order model.

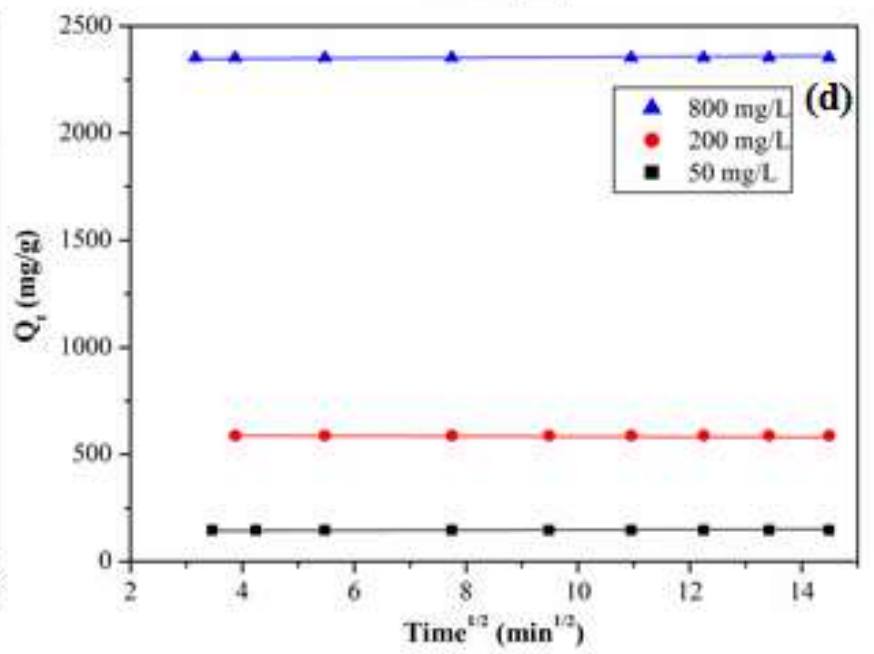

Figure 4. Kinetics adsorption of Cr(VI) by CLDH (a), pseudo-second order model (b), pseudo-first order model (c) and intraparticle diffusion model (d).

The variation in the retention of $\mathrm{CrO}_{4}^{2-}$ by CLDH according to time shows that the adsorption equilibrium is very fast with a maximum experimental retention amount of
$2353 \mathrm{mg} / \mathrm{g}$ for $50 \mathrm{mg}$ of $\mathrm{CLDH}$ and $[\mathrm{Cr}(\mathrm{VI})]=$ $800 \mathrm{mg} / \mathrm{L}$. This result agrees with recent works of the adsorption of Cr(VI) by LDH $[29,30]$. 
Table 1. Parameters of the pseudo-first and pseudo-second order kinetic models and the maximum amounts of $\mathrm{Cr}(\mathrm{VI})$ adsorption

\begin{tabular}{|c|c|c|c|c|c|}
\hline & \multicolumn{5}{|c|}{ Pseudo-first order } \\
\hline $\begin{array}{l}\mathrm{C}_{0} \\
(\mathrm{mg} / \mathrm{L})\end{array}$ & $\begin{array}{l}\text { Equation } \\
\log \left(Q_{e}-Q_{t}\right)=\end{array}$ & $\begin{array}{l}\mathrm{k}_{1} \\
\left(\min ^{-1}\right)\end{array}$ & $\begin{array}{l}\mathrm{Q}_{\mathrm{e}^{\text {th }}} \\
(\mathrm{mg} / \mathrm{g})\end{array}$ & $\begin{array}{l}Q_{e} \exp \\
(m g / g)\end{array}$ & $\mathrm{R}^{2}$ \\
\hline 50 & $-0.0031 \times t-3.0645$ & 0.003 & 147 & 0.047 & 0.017 \\
\hline 200 & $-0.0111 \times t-1.9262$ & 0.011 & 588 & 0.146 & 0.233 \\
\hline \multirow[t]{2}{*}{800} & $-0.0010 \times \mathrm{t}-1.2483$ & 0.001 & 2500 & 0.287 & 0.013 \\
\hline & \multicolumn{5}{|c|}{ Pseudo-second order } \\
\hline $\begin{array}{l}\mathrm{C}_{0} \\
(\mathrm{mg} / \mathrm{L})\end{array}$ & $\begin{array}{l}\text { Equation } \\
\mathrm{t} / \mathrm{Q}_{\mathrm{t}}=\end{array}$ & $\begin{array}{l}\mathrm{k}_{2} \\
(\mathrm{~g} / \mathrm{mg} / \mathrm{min})\end{array}$ & $\begin{array}{l}Q_{e^{\text {th }}} \\
(\mathrm{mg} / \mathrm{g})\end{array}$ & $\begin{array}{l}Q_{e^{\exp }} \\
(\mathrm{mg} / \mathrm{g})\end{array}$ & $\mathrm{R}^{2}$ \\
\hline 50 & $0.0068 \times \mathrm{t}-5 \times 10^{-6}$ & 0.108 & 147 & 147 & 1 \\
\hline 200 & $0.0017 \times t-1 \times 10^{-6}$ & 0.346 & 588 & 588 & 1 \\
\hline 800 & $0.0004 \times t-8 \times 10^{-8}$ & 0.500 & 2500 & 2353 & 1 \\
\hline
\end{tabular}

The intraparticle diffusion model was used to evaluate its contribution in the retention process, it can be expressed by Eq. (4) [28]:

$\mathrm{Q}_{\mathrm{t}}=\mathrm{K}_{\mathrm{id}} \times \mathrm{t}^{1 / 2}+\mathrm{C}$

With $K_{i d}$ is the kinetic constant of intraparticle diffusion $\left(\mathrm{mg} / \mathrm{g} / \mathrm{min}^{1 / 2}\right)$ and $\mathrm{C}$, the thickness of the double layer $(\mathrm{mg} / \mathrm{g})$.

Figure $4 \mathrm{~d}$ shows single linearity for each concentration $(50,200$ and $800 \mathrm{mg} / \mathrm{L})$. This observation indicates that the adsorption process takes place in one step. We can consider that the existence of a single step is probably attributed to the diffusion of $\mathrm{CrO}_{4}{ }^{2-}$ between $\mathrm{LDH}$ sheets with reaching state of equilibrium.
This result indicates that the retention is rapid, suggesting the achievement of a saturation state, and the reconstruction of an anionic clay with adsorption on the surface and insertion of $\mathrm{CrO}_{4}{ }^{2-}$ between the reconstructed LDH sheets. The interaction between $\mathrm{LDH}$ and $\mathrm{Cr}(\mathrm{VI})$ is probably affected by the presence of a hydrogen bond between the hydroxyl group $(\mathrm{OH})$ of the layer of reconstructed $\mathrm{LDH}$ and the oxygen of the chromate anion $\left(\mathrm{CrO}_{4}{ }^{2-}\right)$.

The constants for intraparticle diffusion are provided in Table 2. The rate constants $\mathrm{K}_{\mathrm{id}}$ are directly evaluated from the inclines of the straight lines. Some information is given from the constant $\mathrm{C}$ values such as the transfer 
resistance of the quantity of external mass of the adsorbate [31]. The constant $\mathrm{C}$ increases from 147 to $2353 \mathrm{mg} / \mathrm{g}$ as the pollutant concentrations increases from 50 to $800 \mathrm{mg} / \mathrm{L}$. This indicates a decrease in the chances of external mass transfer, thus increasing the chances of internal mass transfer [32-34]. The values of $\mathrm{R}^{2}$ are not all close to unity, which calls into question the applicability of this model alone. The linearity of the curves can demonstrate the role of intraparticle diffusion in the retention of $\mathrm{Cr}(\mathrm{VI})$ by CLDH. However, some authors have shown that if intraparticle diffusion is the only limiting step, it is necessary that the $Q_{t}$ versus $t^{1 / 2}$ curves cross the origin $[35,36]$, which is not the case in Figure 4d. Therefore, the model of intraparticle diffusion cannot be the only step in these conditions [37]. It should be concluded that the adsorption in the surface and the diffusion function simultaneously during the contact of $\mathrm{Cr}$ (VI) with CLDH.

Table 2. Parameters of the kinetic model for intraparticle diffusion of $\mathrm{Cr}(\mathrm{VI})$

\begin{tabular}{|l|l|l|l|}
\hline $\begin{array}{l}\mathrm{C}_{0} \\
(\mathrm{mg} / \mathrm{L})\end{array}$ & $\begin{array}{l}\mathrm{K}_{\mathrm{id}} \\
\left(\mathrm{mg} / \mathrm{g} / \mathrm{min}^{1 / 2}\right)\end{array}$ & $\begin{array}{l}\mathrm{C} \\
(\mathrm{mg} / \mathrm{g})\end{array}$ & $\mathrm{R}^{2}$ \\
\hline 50 & 0.0014 & 147 & 0.981 \\
\hline 200 & 0.0004 & 588 & 0.952 \\
\hline 800 & 0.0002 & 2353 & 0.936 \\
\hline
\end{tabular}

Thermodynamic parameters
Thermodynamic parameters are investigated to examine the impact of the temperature on $\mathrm{Cr}(\mathrm{VI})(800 \mathrm{mg} / \mathrm{L})$ adsorption on CLDH (50 mg). The parameters concerned, $\Delta \mathrm{S}^{\circ}$ (entropy), $\Delta \mathrm{H}^{\circ}$ (enthalpy) and $\Delta \mathrm{G}^{\circ}$ (Gibbs free energy), were identified using Eqs. (5-7):

$\mathrm{K}_{\mathrm{c}}=\mathrm{Q}_{\mathrm{e}} / \mathrm{C}_{\mathrm{e}}$

$\operatorname{Ln}\left(\mathrm{K}_{\mathrm{c}}\right)=\left(\Delta \mathrm{S}^{\circ} / \mathrm{R}\right)-\left(\Delta \mathrm{H}^{\circ} / \mathrm{RT}\right)$

$\Delta \mathrm{G}^{\circ}=-(\mathrm{RT}) \times \operatorname{Ln}\left(\mathrm{K}_{\mathrm{c}}\right)$

$\mathrm{K}_{\mathrm{c}}$ represents the constant at equilibrium, $\mathrm{R}$, the ideal gas constant and $\mathrm{T}$, the solution temperature. From the obtained results (Table 3), the value of $\Delta \mathrm{H}^{\circ}$ indicates that this adsorption is endothermic and $\Delta G^{\circ}$ suggests the spontaneity of retention of this pollutant $[38,39]$. The value of $\Delta \mathrm{H}^{\circ}(28.39 \mathrm{~kJ} / \mathrm{mol})$ indicates that the mechanism of adsorption of $\mathrm{Cr}(\mathrm{VI})$ by $\mathrm{CLDH}$ is physical. $\Delta \mathrm{S}^{\circ}>0$ implies the existence of a disorder at the adsorbate-adsorbent interface [40].

$E_{a}$ represents the energy of activation is linked to the pseudo-second model rate constant $\left(\mathrm{k}_{2}\right)$ by the following Arrhenius relation:

$\operatorname{Ln}\left(\mathrm{k}_{2}\right)=\operatorname{Ln}(\mathrm{A})-\mathrm{E}_{\mathrm{a}} / \mathrm{RT}$

Where A is the Arrhenius factor.

The value of $E_{a}(22.32 \mathrm{~kJ} / \mathrm{mol})$ confirms that the retention mechanism is governed by a physisorption [41]. Other researchers have reported similar results in recent works $[42,43]$. 
Table 3. Thermodynamic parameters obtained by adsorption of $\mathrm{Cr}(\mathrm{VI})$ on CLDH at different temperatures

\begin{tabular}{|c|c|c|c|c|c|}
\hline $\begin{array}{l}\mathrm{T} \\
(\mathrm{K})\end{array}$ & $\begin{array}{l}\mathrm{E}_{\mathrm{a}} \\
(\mathrm{kJ} / \mathrm{mol})\end{array}$ & $\operatorname{Ln} K_{c}$ & $\begin{array}{l}\Delta \mathrm{G}^{\circ} \\
(\mathrm{kJ} / \mathrm{mol})\end{array}$ & $\begin{array}{l}\Delta \mathrm{H}^{\circ} \\
(\mathrm{kJ} / \mathrm{mol})\end{array}$ & $\begin{array}{l}\Delta \mathrm{S}^{\circ} \\
(\mathrm{J} / \mathrm{mol} / \mathrm{K})\end{array}$ \\
\hline 298 & \multirow{3}{*}{22.32} & 9.757 & -24.17 & \multirow{3}{*}{28.39} & \multirow{3}{*}{175.56} \\
\hline 318 & & 10.131 & - 26.78 & & \\
\hline 333 & & 11.010 & - 30.48 & & \\
\hline
\end{tabular}

Isotherms models of adsorption

The linear transformations of Langmuir and Freundlich isotherm models are represented respectively by Eqs. (9) and (10) [28]:

$\mathrm{C}_{\mathrm{e}} / \mathrm{Q}=1 /\left(\mathrm{KQ}_{\mathrm{m}}\right)+\mathrm{C}_{\mathrm{e}} / \mathrm{Q}_{\mathrm{m}}$

$\operatorname{Ln} \mathrm{Q}_{\mathrm{e}}=\mathrm{Ln} \mathrm{K}_{\mathrm{F}}+1 / \mathrm{n} \times \operatorname{Ln} \mathrm{C}_{\mathrm{e}}$

With K: the Langmuir constant; $\mathrm{Q}_{\mathrm{m}}$ : the maximum adsorbed amount $(\mathrm{mg} / \mathrm{g}) ; \mathrm{n}$ and $\mathrm{K}_{\mathrm{F}}$ : the Freundlich constants.
The study of adsorption isotherms makes it possible to determine the adsorption capacity of $\mathrm{CrO}_{4}{ }^{2-}$ on the adsorbent (CLDH) and the type of adsorption mechanism. This study is realized with different concentrations of pollutant and for different masses of CLDH equal to 30, 50 and 80 $\mathrm{mg}$ for $30 \mathrm{~min}$ stirring at $\mathrm{pH} 7$ and at $\mathrm{T}=25^{\circ} \mathrm{C}$. Figure 5a illustrates the evolution of the adsorbed amount at equilibrium versus the residual concentration of $\mathrm{Cr}(\mathrm{VI})$. The obtained graphs display that the isotherms are of L type [44]. 

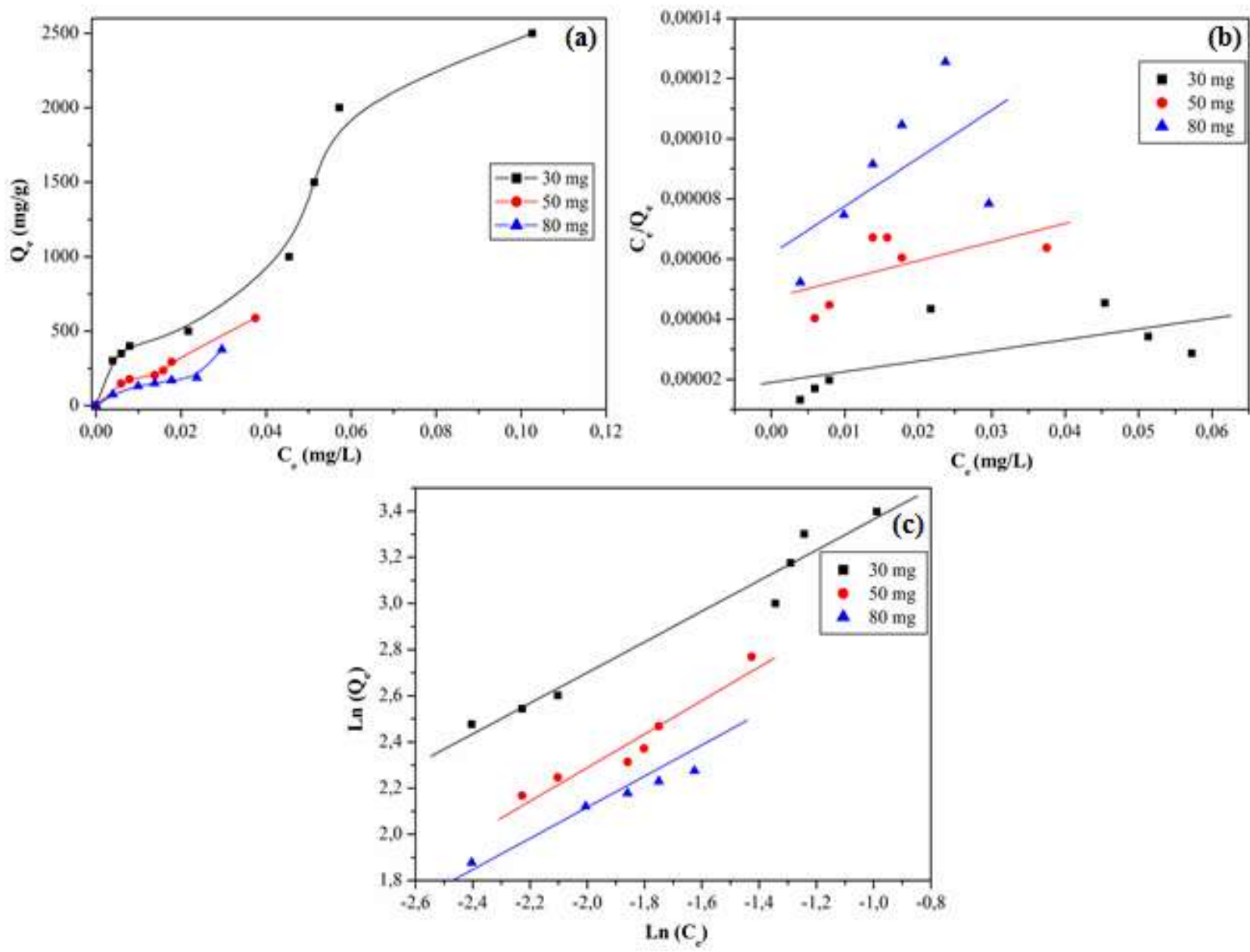

Figure 5. Adsorption isotherms (a) and linear representation of the Langmuir (b) and Freundlich (c) models of $\mathrm{Cr}(\mathrm{VI})$ adsorption by CLDH.

Figure $5 \mathrm{~b}$ illustrates the linear plots of the In Table 4, we present the parameters adsorption isotherms according to the Langmuir corresponding to these two models. model and Figure 5c represents the linearization by the Freundlich model.

Table 4. Parameter values of Langmuir and Freundlich models for adsorption of Cr(VI) by CLDH

\begin{tabular}{|l|l|l|l|l|l|l|}
\cline { 2 - 7 } \multicolumn{1}{c|}{} & \multicolumn{2}{l|}{ Langmuir model } & \multicolumn{2}{l|}{ Freundlich model } \\
\hline $\begin{array}{l}\mathrm{m}_{\text {CLDH }} \\
(\mathrm{mg})\end{array}$ & $\begin{array}{l}\mathrm{Q}_{\mathrm{m}} \\
(\mathrm{mg} / \mathrm{g})\end{array}$ & $\begin{array}{l}\mathrm{K} \\
(\mathrm{L} / \mathrm{mg})\end{array}$ & $\mathrm{R}^{2}$ & $\begin{array}{l}\mathrm{K}_{\mathrm{F}} \\
(\mathrm{mg} / \mathrm{g})\end{array}$ & $\mathrm{n}$ & $\mathrm{R}^{2}$ \\
\hline 30 & 3333 & 30.00 & 0.801 & 54.64 & 1.447 & 0.982 \\
\hline 50 & 1667 & 11.99 & 0.353 & 42.13 & 1.377 & 0.962 \\
\hline 80 & 625 & 26.67 & 0.341 & 31.98 & 1.937 & 0.989 \\
\hline
\end{tabular}


This result suggests that the model of Freundlich represents perfectly the mechanism of retention, with correlation factor near to unit. The Freundlich model relates the energy required to retain the adsorbate and the number of sites of the adsorbent material [45].

However, $\mathrm{K}_{\mathrm{F}}$ and $\mathrm{n}$ are characteristic parameters of the adsorbate-adsorbent, the Freundlich $\mathrm{K}_{\mathrm{F}}$ constant is linked to the adsorption amount of $\mathrm{Cr}(\mathrm{VI})$. This constant increases when the experimental value of $\mathrm{Q}$ increases. The $\mathrm{n}$ factor is higher than 1, suggesting a favorable retention process and that the retention sites are homogeneous $[46,47]$. The process is explained probably by the fixation of $\mathrm{CrO}_{4}{ }^{2-}$ anions by hydrogen bonds and electrostatic interactions with the hydroxyl groups of the LDH sheets. Similar results have been reported by other authors for $\mathrm{Cr}(\mathrm{VI})$ adsorption by $\mathrm{MgAlFe}-\mathrm{LDH}$ [48], by CoBi-LDH [49], and by calcined material based on zinc and aluminum and $\mathrm{ZnAl} / \mathrm{Fe}_{3} \mathrm{O}_{4}[27]$.

\section{Effect of mass ratio $\mathrm{Cr}(\mathrm{VI}) / \mathrm{CLDH}$}

This study shows that the total elimination $(100 \%)$ is obtained for a mass ratio $\mathrm{Cr}(\mathrm{VI}) / \mathrm{CLDH}$ between 0.075 and 8 (Figure 6). We can consider that the optimum adsorbate/adsorbent ratio is 8 and the experimental retention capacity achieved 3333 $\mathrm{mg} / \mathrm{g}$.

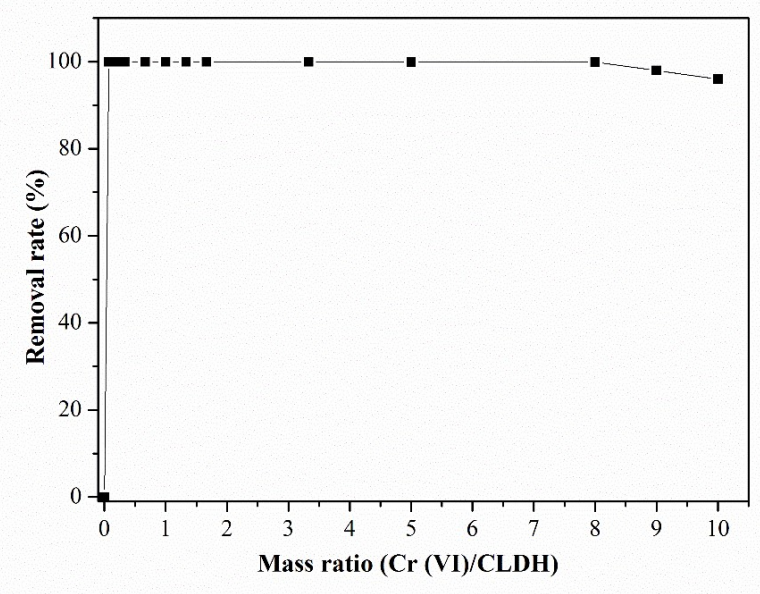

Figure 6. Removal rate of $\mathrm{Cr}(\mathrm{VI})$ as a function of the mass ratio $\mathrm{Cr}(\mathrm{VI}) / \mathrm{CLDH}$.

\section{Analysis by XRD, IR and TGA/DTG}

The diffractograms of X-ray are shown in Figure $7 \mathrm{a}$. For the calcined phase $(\mathrm{CLDH})$, we note the destruction of LDH phase after calcination with the appearance of $\mathrm{ZnO}$ in amorphous form. After rehydration, the retention of the $\mathrm{CrO}_{4}{ }^{2-}$ anions lead to the reconstruction of a single LDH phase characterized by an interlamellar distance of $0.902 \mathrm{~nm}$, which confirms the insertion of the chromate anions between the LDH sheets. Figure $7 \mathrm{~b}$ represents the IR spectrum of the phase obtained after adsorption of $\mathrm{Cr}(\mathrm{VI})$ by $\mathrm{CLDH}$. The infrared spectrum of CLDH results in a band at $3430 \mathrm{~cm}^{-}$

${ }^{1}$ which corresponds to the vibrations of $\mathrm{OH}$ and by metal-oxygen vibrations with a $\mathrm{Zn}-\mathrm{O}$ band at $615 \mathrm{~cm}^{-1}$ and that of Al-O at $553 \mathrm{~cm}^{-1}$ [50]. On the spectrum of $\mathrm{K}_{2} \mathrm{CrO}_{4}$ (Figure $7 \mathrm{~b}$ ), we can note on either side of the main band at $890 \mathrm{~cm}^{-1}$, which is attributed to the symmetrical molecular vibration $v(\mathrm{Cr}-\mathrm{O})$, the existence of a shoulder at 
$943 \mathrm{~cm}^{-1}$ which may suggest a lower symmetry of the chromate anion. This is apparently due to the deformation of the chromate anion caused by the high pressures used to shape the samples to be analyzed [51]. From the obtained results after retention of $\mathrm{Cr}(\mathrm{VI})$ by $\mathrm{CLDH}$, it can be seen on the corresponding IR spectrum (Figure $7 b$ ) that the bands around $400 \mathrm{~cm}^{-1}$ are characteristic of LDH sheets reconstructed from mixed oxides. The wide and intense band at about $3430 \mathrm{~cm}^{-1}$ corresponds to the $\mathrm{OH}$ valence vibrations, and the band around $1430 \mathrm{~cm}^{-1}$ is characteristic of the vibration band of carbonate anions $v\left(\mathrm{CO}_{3}{ }^{2-}\right)$. The characteristic bands of the matrix sheets correspond to the metal-oxygen vibrations for (Zn-O) around $615 \mathrm{~cm}^{-1}$ and for (Al-O) around $554 \mathrm{~cm}^{-1}$. Finally the bands of 750 to $920 \mathrm{~cm}^{-1}$ are characteristic of the chromate anion vibration bands $\left(\mathrm{CrO}_{4}{ }^{2-}\right)[30,51,52]$. The band appearing at $880 \mathrm{~cm}^{-1}$ is characteristic of the $v_{3}$ vibration of chromate anions. The $v_{2}$ and $v_{4}$ vibrations of chromate ions, at 348 and $368 \mathrm{~cm}^{-1}$ respectively [53], are outside the frequency domain explored. The vibration $v_{1}$ at $847 \mathrm{~cm}^{-1}$ [53] very close to the vibration $v_{3}$ is probably masked by the characteristic band of the latter. We are therefore led to argue our analysis, only from a possible bursting or not of the vibration $v_{3}$. The shoulder of this vibration which appears around $917 \mathrm{~cm}^{-1}$ indicates a lowering of the symmetry; it can be attributed to the elongations (Cr-O) [51]. In addition, if we consider the band detectable at $780 \mathrm{~cm}^{-1}$ as a burst of the vibration $v_{3}$, then we can estimate that the chromate anions are totally linked or more exactly bi-linked taking into account the bursting mode $v_{3}$ in three bands and their relatively high difference of about $137 \mathrm{~cm}^{-1}$ characteristic of this bi-linked state [54].

The thermogravimetric analyses curve in Figure 7 cshows the different thermal events occurring in this phase intercalated by the chromate anions. First, the surface $\mathrm{H}_{2} \mathrm{O}$ molecules evaporate up to $100{ }^{\circ} \mathrm{C}$. Then between 100 and $200^{\circ} \mathrm{C}$, a loss which clearly differs from the first is attributed to the interlamellar water. Above this temperature and up to $400-450{ }^{\circ} \mathrm{C}$, the dehydroxylation of the layers of $\mathrm{LDH}\left[\mathrm{Zn}_{2}-\mathrm{Al}\right.$ $\left.\mathrm{CrO}_{4}\right]$ is observed. It can be noted that the last loss may be due either to the elimination of the pollutant or to a reduction of chromium.

The characterization by XRD (Figure 7d) of the residual product of the heat treatment shows chromium enrichment due to its persistence, which results in the arrangement of a spinel form contains the chromium. However, it can be noted that the transformation of $\mathrm{Cr}(\mathrm{VI})$ into $\mathrm{Cr}$ (III) occurs around $460{ }^{\circ} \mathrm{C}$ as suggested by the thermogravimetric curve. The spinel phase resulting from the thermal decomposition of $\left[\mathrm{Zn}_{2}-\mathrm{Al}-\mathrm{CrO}_{4}\right]$ has a lattice parameter $\mathrm{a}=0.815$ $\mathrm{nm}$. This value is slightly greater than that recorded for $\mathrm{ZnAl}_{2} \mathrm{O}_{4}(\mathrm{a}=0.808 \mathrm{~nm})$, given the incorporation of chromium whose ionic radius $\left(\mathrm{r}_{\mathrm{Cr}}^{\mathrm{III}}=0.069 \mathrm{~nm}\right)$ is higher than that of aluminum $\left(\mathrm{r}_{\mathrm{Al}}^{\mathrm{III}}=0.050 \mathrm{~nm}\right)$. Recall also that the spinel phase $\mathrm{ZnCr}_{2} \mathrm{O}_{4}$ has a lattice parameter $\mathrm{a}=0.832$ 
$\mathrm{nm}$ [54]. We can therefore think that we are in of LDH intercalated by the carbonate anions [2], the presence of a mixed spinel $\mathrm{Zn}\left(\mathrm{Al}_{2 / 3} \mathrm{Cr}_{1 / 3}\right)_{2} \mathrm{O}_{4}$. it can be concluded that the product obtained The relative proportions of aluminum and after retention of the chromate anions is singlechromium take into account that there is twice as phase and therefore has no carbonate anions much aluminum as chromium in the starting between the layers. This result consolidates those compound $\left[\mathrm{Zn}_{2}-\mathrm{Al}-\mathrm{CrO}_{4}\right]$.

obtained with the other characterization techniques and thus confirms the retention of

Finally, from the thermogram of $\left[\mathrm{Zn}_{2}-\mathrm{Al}-\mathrm{Cr}(\mathrm{VI})\right.$ pollutant by CLDH.

$\left.\mathrm{CrO}_{4}\right]$ which has a shape which differs from that
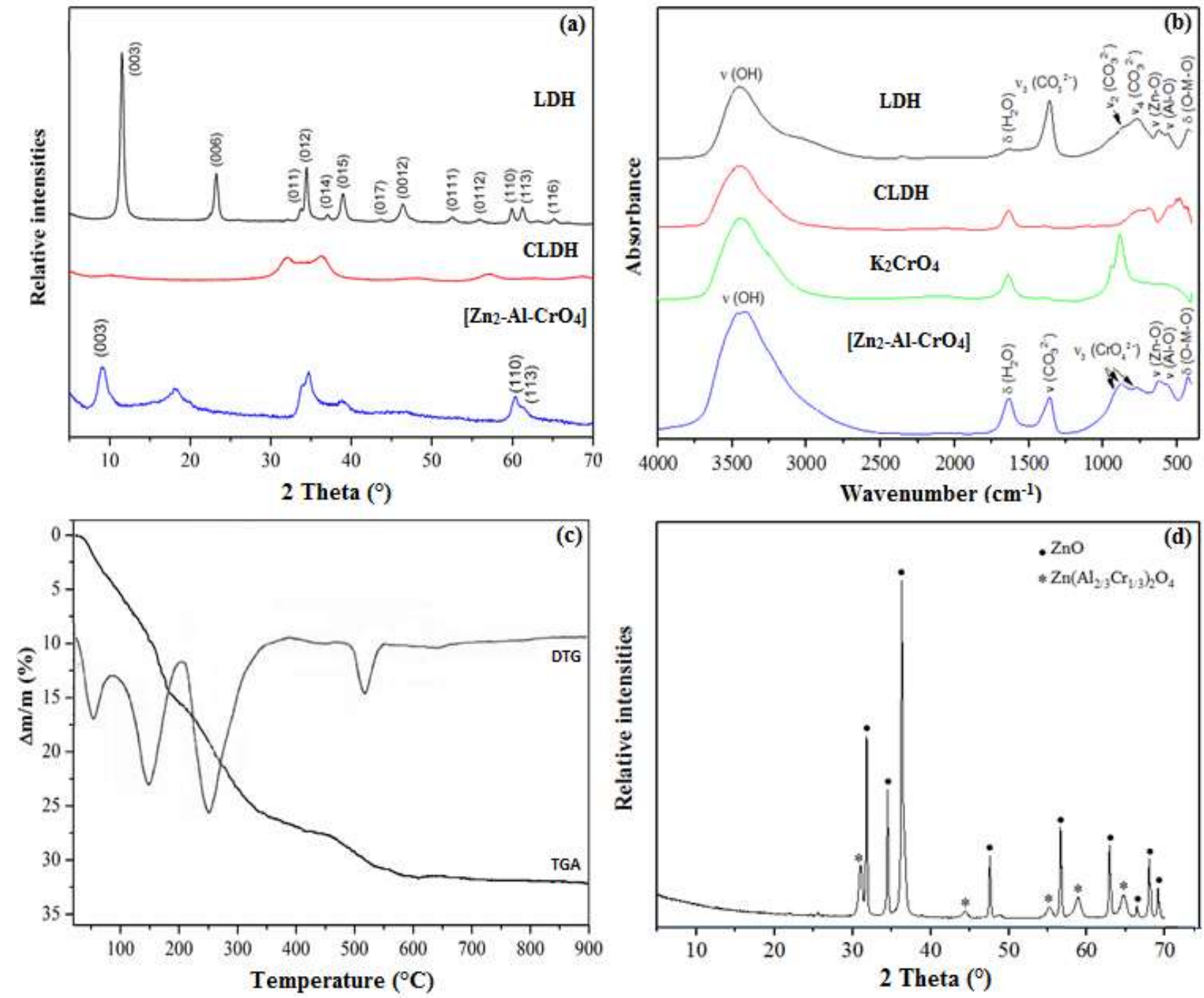

Figure 7. X-ray diffractograms of $\mathrm{LDH}, \mathrm{CLDH}$ and $\left[\mathrm{Zn}_{2}-\mathrm{Al}-\mathrm{CrO}_{4}\right]$ phase obtained after retention of $\mathrm{CrO}_{4}^{2-}(\mathrm{a})$; IR spectra (b); TGA/DTG curves of $\left[\mathrm{Zn}_{2}-\mathrm{Al}-\mathrm{CrO}_{4}\right]$ (c) and X-ray diffractogram of the $\left[\mathrm{Zn}_{2}-\mathrm{Al}-\mathrm{CrO}_{4}\right]$ phase calcined at $900{ }^{\circ} \mathrm{C}(\mathrm{d})$. 
lamellar character which may be due to the destruction of the LDH phase with the appearance of aggregates probably corresponding to mixed oxides.

Figure $8 \mathrm{~b}$ gives the SEM image corresponding to the phase obtained after retention of $\mathrm{CrO}_{4}{ }^{2-}$. The sample studied shows aggregates consisting of crystallites perpendicular or parallel to the image. These crystallites are of different sizes may go up to

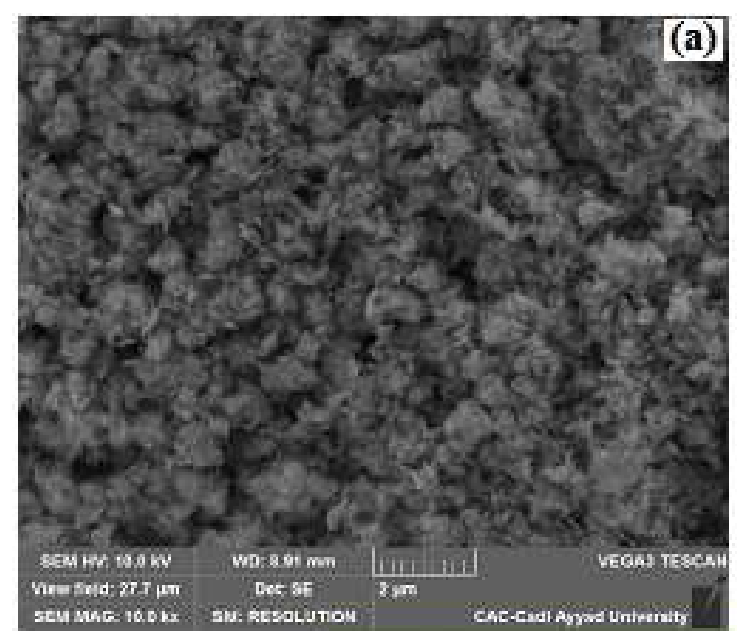

$1.78 \mu \mathrm{m}$. This lamellar character proves the reconstruction of the LDH phase from mixed oxides through their memory effect kept from the starting LDH $[46,55]$. The EDS analysis of the $\left[\mathrm{Zn}_{2}-\mathrm{Al}-\mathrm{CrO}_{4}\right]$ phase was carried out on distinct points in the same crystal. The X-ray emission spectrum showed, in addition to zinc and aluminum emissions, the presence of chromium and oxygen (Figure 8c), confirming the intercalation of $\mathrm{CrO}_{4}{ }^{2-}$.
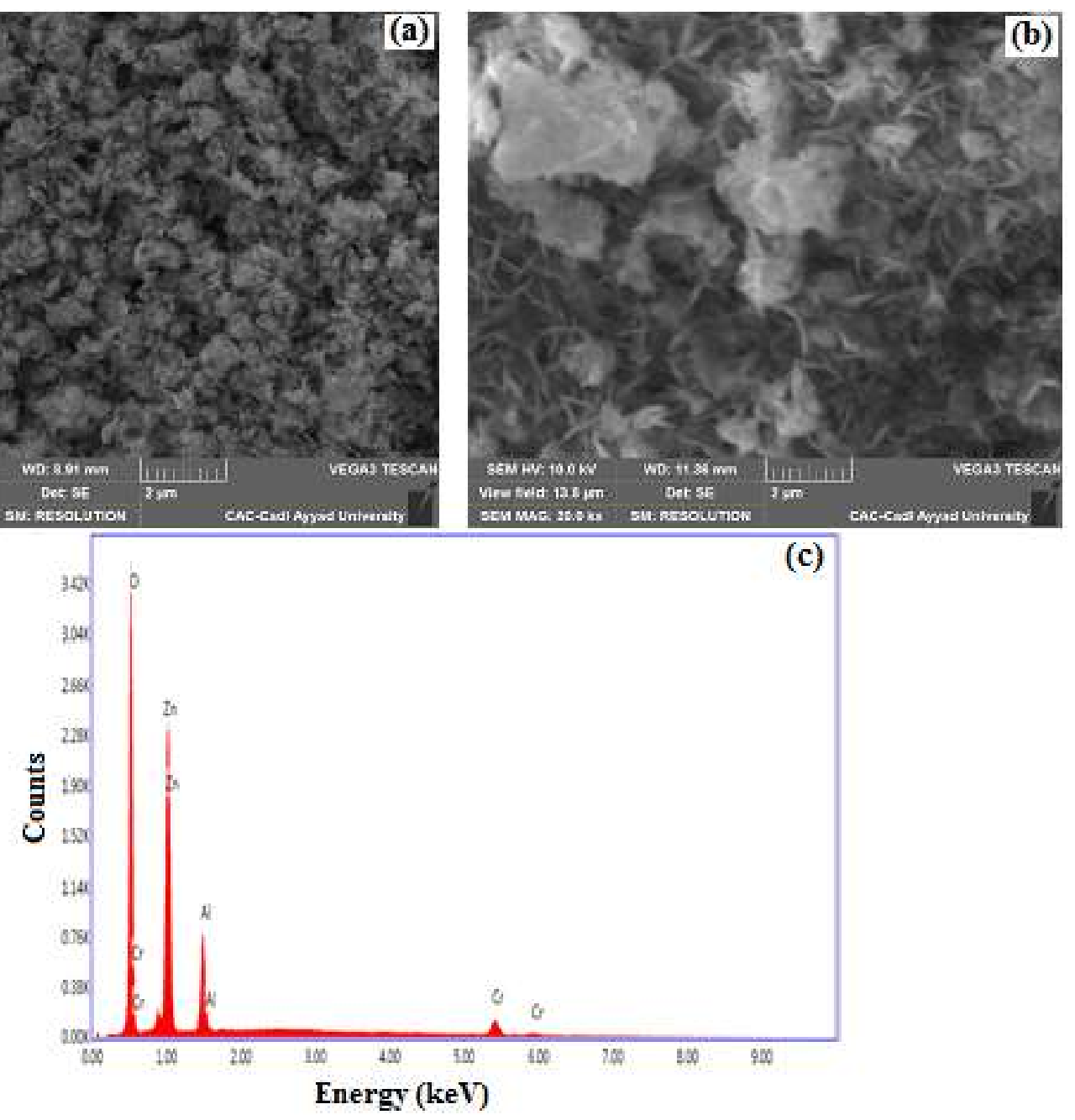

Figure 8. SEM photographs of CLDH (a) and of $\left[\mathrm{Zn}_{2}-\mathrm{Al}-\mathrm{CrO}_{4}\right]$ obtained after retention of $\mathrm{Cr}(\mathrm{VI})(\mathrm{b})$, and $\mathrm{X}$-ray emission spectrum of the $\left[\mathrm{Zn}_{2}-\mathrm{Al}-\mathrm{CrO}_{4}\right]$ phase (c).

Structural model

In light of these results, we can confirm that the chromate anion is intercalated in the 
interlamellar space and linked to the reconstructed phase by hydrogen bonding with a distance between the sheets of $0.902 \mathrm{~nm}$. Knowing the thickness of the brucitic-type layer $(\mathrm{e}=0.21 \mathrm{~nm})$ and hydrogen bonds distance that is $0.27 \mathrm{~nm}$, we can determine the value of the $\mathrm{CrO}_{4}{ }^{2-}$ anion length by the semi-empirical method with Gaussian 03 software.

According to previous work [54,56], tetrahedral geometry anions can be housed between LDH sheets by adopting two possible arrangements:

- With three oxygen atoms pointing to a hydroxyl plane and the fourth oriented to the other hydroxyl plane. This arrangement corresponds to the maximum deviation and will give a calculated interlamellar distance of the order of $0.22 \mathrm{~nm}$.

- With two atoms of oxygen pointing on each of the adjacent hydroxyl planes. This is a provision which corresponds to the minimum spacing and will give a distance of the order of $0.18 \mathrm{~nm}$. This last disposition is that which is in conformity with the distance found experimentally.

This value is comparable to that reported by other authors allowing favoring an orientation of the chromate anion between the LDH sheets consistent with the proposal of Pan et al. [57,58]. The chromate anions are arranged along the axis $\mathrm{C}_{2}$ perpendicular to the sheets with an experimental interlamellar distance $\mathrm{d}=0.902$ nm. Figure 9 display the orientation of $\mathrm{CrO}_{4}{ }^{2-}$ intercalated between the sheets of reconstructed LDH.

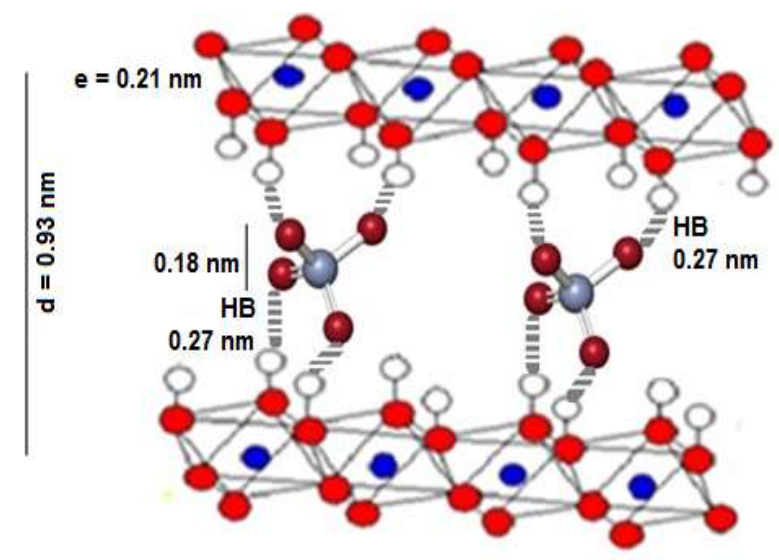

Figure 9. Structural model of the orientation of $\mathrm{CrO}_{4}^{2-}$ between LDH sheets.

The distance can be calculated from particle size and the length of bonds:

$d=0.21+0.27+0.27+0.18=0.93 \mathrm{~nm} \approx 0.902 \mathrm{~nm}$

Although the experimental value is slightly less than that calculated, this is due to the existence of hydrogen bonds (LH) and electrostatic interactions among $\mathrm{CrO}_{4}{ }^{2-}$ and the LDH sheets. This is probably leading to a slight contraction of the chromate anion that is $\mathrm{Cr}-\mathrm{O}$ bond lengths and $\mathrm{O}-\mathrm{Cr}-\mathrm{O}$ angles decrease slightly after intercalation of the $\mathrm{CrO}_{4}{ }^{2-}$ anion between LDH sheets [30,58,59]. The water molecules are always present in the interlamellar area; they probably take place between the chromate anions because they do not intervene in the determination of the gallery space in our experimental conditions.

\section{Recycling study of adsorbent material}

The efficiency of elimination of the pollutant by $\mathrm{CLDH}$ corresponds to the $\mathrm{CrO}_{4}{ }^{2-}$ anions 
retained after a series of cycles using the optimal ratio $(\mathrm{Cr}(\mathrm{VI}) / \mathrm{CLDH}=8)$ which corresponds to total elimination of $\mathrm{Cr}(\mathrm{VI})$. Regeneration takes place through a series of cycles, each of which includes calcination-rehydration-retention of polluting anions and their exchange by carbonate anions and then recalcination. The chromate removal rate is evaluated by Eq. (11):

$\%$ Removal rate $=\left(\left(\mathrm{C}_{\mathrm{i}}-\mathrm{C}_{\mathrm{e}}\right) / \mathrm{C}_{\mathrm{i}}\right) \times 100$
Figure 10 shows the percentage of $\mathrm{Cr}(\mathrm{VI})$ removed from the different solutions after $\mathrm{Cr}(\mathrm{VI})$ retention and exchange reactions with carbonate anions $\left(\mathrm{Na}_{2} \mathrm{CO}_{3}\right)$. Examination of the graph shows that the removal rate of $\mathrm{Cr}(\mathrm{VI})$ increases from $100 \%$ to $99.5 \%$ after the sixth regeneration cycle. This decrease, which does not exceed $0.5 \%$, indicates that the material used is an interesting adsorbent material because it shows a great capacity for regeneration.

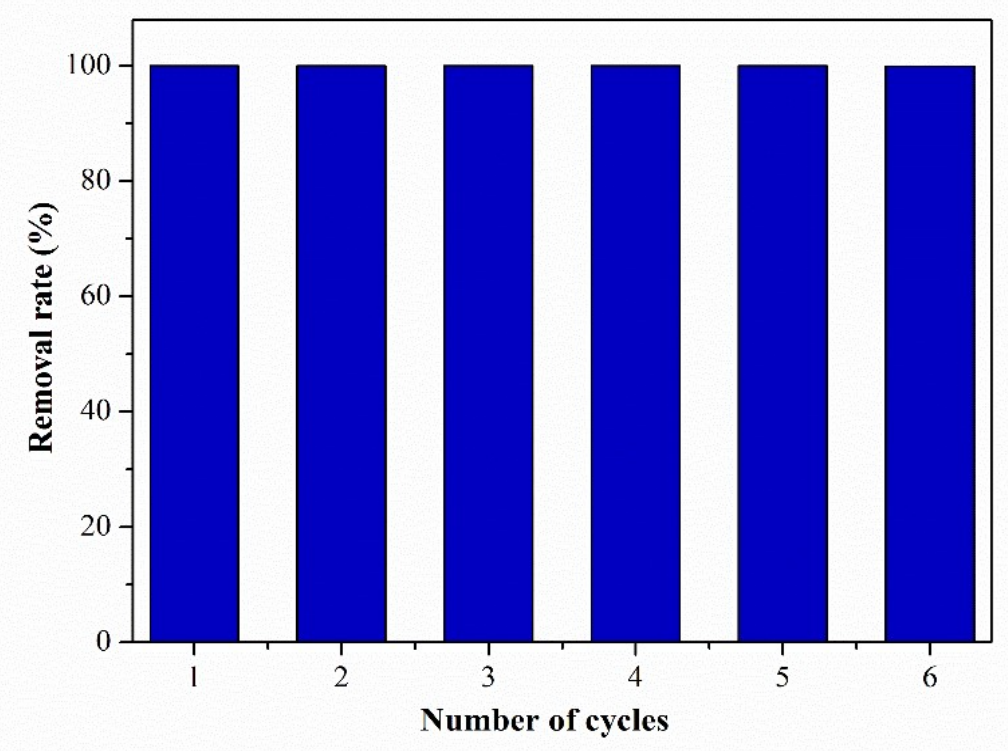

Figure 10. Retention rate of $\mathrm{Cr}(\mathrm{VI})$ by $\mathrm{CLDH}$ after six cycles of regeneration.

\section{Comparative study}

Many materials are used for the removal of hexavalent chromium such as activated carbon, biocomposites, ion exchangers, modified fly ash, etc. In this section, we will compare the results of this study with those cited by other authors based on the removal rate and the maximum retention capacity of $\mathrm{Cr}$ (VI) with different adsorbent materials (Table 5). 
Table 5. Comparison of the removal rate and the adsorption capacity of $\mathrm{Cr}(\mathrm{VI})$ by different adsorbent materials

\begin{tabular}{|c|c|c|c|}
\hline Adsorbent materials & $\begin{array}{l}\mathrm{Q}_{\mathrm{m}} \\
(\mathrm{mg} / \mathrm{g})\end{array}$ & $\begin{array}{l}\text { Removal } \\
\text { rate }(\%)\end{array}$ & References \\
\hline Calcined anionic clay & 3333 & 100 & This study \\
\hline Granular Ferric Hydroxide (GFH) & 13.69 & 100 & {$[60]$} \\
\hline $\begin{array}{l}\text { Amino-functionalized MIL-101(Cr) } \\
\text { (AFMIL) MOF }\end{array}$ & 44 & 73.6 & [61] \\
\hline Activated carbon based on wood & 70.95 & 40.04 & {$[62]$} \\
\hline Zinc chloride activated biomass & 314.4 & 100 & {$[63]$} \\
\hline Graphene oxide & 1.22 & 92.8 & [64] \\
\hline LDH MgAl & 88.07 & - & {$[65]$} \\
\hline Synthetic hydrothermal LDH & 68.07 & 96 & {$[46]$} \\
\hline Calcined $\mathrm{Mg}-\mathrm{Al}-\mathrm{CO}_{3}$ & 120 & - & [29] \\
\hline $\begin{array}{l}\text { ZnAl layered double hydroxide sheet } \\
\text { microphones }\end{array}$ & 223.24 & 98 & [59] \\
\hline Modified fly ash & 12.34 & 97.48 & {$[66]$} \\
\hline $\begin{array}{l}\text { Manganese powder extracted from the } \\
\text { battery }\end{array}$ & 125 & 40.80 & [67] \\
\hline Graphene oxide/polyamidoamine & 90.7 & 72.8 & {$[68]$} \\
\hline Calcined $\mathrm{ZnAl}$ and $\mathrm{Fe}_{3} \mathrm{O}_{4} / \mathrm{ZnAl}$ & 23.6 & 90 & {$[27]$} \\
\hline $\begin{array}{l}\text { Freshwater Snail Shells (FSSs) } \\
\text { containing } \mathrm{CaCO}_{3}\end{array}$ & 8.85 & 41.86 & {$[69]$} \\
\hline Ca-Al layered double hydroxide & 59.45 & 96.7 & {$[70]$} \\
\hline Manganese oxides and boehmite & 178.85 & 100 & [71] \\
\hline Chitosan and poly(1-vinylimidazole) & 196.1 & 55 & {$[72]$} \\
\hline Dried water hyacinth root (DWHR) & 1.28 & 95.43 & {$[73]$} \\
\hline
\end{tabular}

According to this comparative study, it is noted that the elimination of $\mathrm{Cr}(\mathrm{VI})$ by $\mathrm{CLDH}$ which is total $(100 \%)$, is greater than that obtained with other materials. With a retention capacity reaches $3333 \mathrm{mg} / \mathrm{g}$, CLDH can be classified as having relatively a very high capacity. This makes this material more efficient compared to the other adsorbents cited in the literature and therefore can be considered promising for eliminating such pollutants. 


\section{Conclusion}

In aqueous solution, calcined anionic clay based on $\mathrm{Zn}$ and $\mathrm{Al}$ has shown its adsorption efficiency for $\mathrm{Cr}(\mathrm{VI})$. From the obtained results, it can be considered that the amount of retention increases when the mass of CLDH decreases regardless of the initial concentration of the studied pollutant. This leads to confirm that the cost can be reduced by using a few amounts of the adsorbent support for the removal of $\mathrm{Cr}(\mathrm{VI})$. The optimal $\mathrm{pH}$ is 7 and the equilibrium time is 30 min. The pseudo-second order model describes well the adsorption kinetic process. The thermodynamic study confirms that the retention is governed by a physisorption mechanism. The retention process is described by the Freundlich model, which implies that sites of adsorption are homogeneous. The elimination of $\mathrm{Cr}(\mathrm{VI})$ is always almost total after six regeneration cycles with a high retention capacity. This calcined anionic clay has demonstrated its best efficiency for the elimination of this emerging and toxic pollutant, with the opportunity of its good regeneration.

\section{References}

[1] Shahbazi A, Younesi H, Badiei A. Functionalized SBA-15 mesoporous silica by melaminebased dendrimer amines for adsorptive characteristics of $\mathrm{Pb}$ (II), $\mathrm{Cu}$ (II) and $\mathrm{Cd}(\mathrm{II})$ heavy metal ions in batch and fixed bed column. Chemical Engineering Journal 2011; 168(2): 505-518. doi:10.1016/j.cej.2010.11.053

[2] Cocheci L, Barvinschi P, Pode R, Seftel E. Chromium (VI) Ion Removal from Aqueous Solutions Using a Zn-Al-type Layered Double Hydroxide.
Adsorption Science and Technology 2010; 28(8): 267 279. doi:10.1260/0263-6174.28.3.267

[3] Yuan X, Wang Y, Wang J, Zhou C, Tang Q, et al. Calcined graphene/MgAl-layered double hydroxides for enhanced $\mathrm{Cr}(\mathrm{VI})$ removal. Chemical Engineering Journal 2013; 221: 204-213. doi:10.1016/j.cej.2013.01.090

[4] Alvarez P, Blanco C, Granda M. The adsorption of chromium (VI) from industrial wastewater by acid and base-activated lignocellulosic residues. Journal of Hazardous Materials 2007; 144: 400-405. doi:10.1016/j.jhazmat.2006.10.052

[5] Joshi KM, Shrivastava VS. Photocatalytic degradation of Chromium (VI) from wastewater using nanomaterials like $\mathrm{TiO}_{2}, \mathrm{ZnO}$, and $\mathrm{CdS}$. Applied Nanoscience 2011; 1(3): 147-155. doi:10.1007/s13204011-0023-2

[6] Gueye M, Richardson Y, Kafack FT, Blin J. High efficiency activated carbons from African biomass residues for the removal of chromium (VI) from wastewater. Journal of Environmental Chemical Engineering 2014; 2(1): 273-281. doi:10.1016/j.jece.2013.12.014

[7] Huang M, Ai H, Xu X, Chen K, Niu H, et al. Nitric oxide alleviates toxicity of hexavalent chromium on tall fescue and improves performance of photosystem II. Ecotoxicology and environmental safety 2018; 164: 32-40. doi:10.1016/j.ecoenv.2018.07.118

[8] Ramos-Ramírez E, Gutiérrez NL, Contreras CA, Olguín MT. Adsorption isotherm studies of chromium (VI) from aqueous solutions using sol-gel hydrotalcite-like compounds. Journal of Hazardous Materials 2009; 172: 1527-1531. doi:10.1016/j.jhazmat.2009.08.023

[9] Alemu A, Lemma B, Gabbiye N, Alula MT, Desta MT. Removal of chromium (VI) from aqueous solution using vesicular basalt: A potential low cost wastewater treatment system. Heliyon 2018; 4(7): e00682. doi:10.1016/j.heliyon.2018.e00682

[10] Langard S. Chromium carcinogenicity; A review of experimental animal data. Science of the Total 
Environment 1988; 71(3): 341-350. doi:10.1016/00489697(88)90206-9

[11] Loyaux-Lawniczak S, Lecomte P, Ehrhardt J. Behavior of Hexavalent Chromium in a Polluted Groundwater: Redox Processes and Immobilization in Soils. Environmental Science \& Technology 2001; 35: 1350-1357. doi:10.1021/es0010731

[12] Felter SP, Dourson ML. Hexavalent Chromium-Contaminated Soils: Options for Risk Assessment and Risk Management. Regulatory Toxicology and Pharmacology 1997; 25(1): 43-59. doi:10.1006/rtph.1996.1073

[13] Tzou YM, Chen YR, Wang MK. Chromate sorption by acidic and alkaline soils. Journal of Environmental Science and Health A 1998; 33(8): 16071630. doi:10.1080/10934529809376807

[14] Khezami L, Capart R. Removal of chromium (VI) from aqueous solution by activated carbons: Kinetic and equilibrium studies. Journal of Hazardous Materials 2005; 123(1): 223-231.doi:10.1016/j.jhazmat.2005.04.012

[15] Zhou J, Wu P, Dang Z, Zhu N, Wu J, et al. Polymeric Fe/Zr pillared montmorillonite for the removal of $\mathrm{Cr}(\mathrm{VI})$ from aqueous solutions. Chemical Engineering Journal 2010; $\quad 162: \quad 1035-1044$. doi:10.1016/j.cej.2010.07.016

[16] Luo P, Zhang J, Zhang B, Wang J, Zhao Y, et al. Preparation and Characterization of Silane Coupling Agent Modified Halloysite for $\mathrm{Cr}(\mathrm{VI})$ Removal. Industrial \& Engineering Chemistry Research 2011; 50(17): 1024610252. doi:10.1021/ie200951n

[17] Monser L, Adhoum N. Tartrazine modified activated carbon for the removal of $\mathrm{Pb}$ (II), $\mathrm{Cd}$ (II) and Cr(III). Journal of Hazardous Materials 2009; 161(1): 263269. doi:10.1016/j.jhazmat.2008.03.120

[18] Mohan D, Pittman CU. Activated carbons and low cost adsorbents for remediation of tri- and hexavalent chromium from water. Journal of Hazardous Materials 2006; 137: 762-811. doi:10.1016/j.jhazmat.2006.06.060
[19] Jiang Y, Wu Y, Liu J, Xia X, Wang D. Ammonium pyrrolidinedithiocarbamate-modified activated carbon micro-column extraction for the determination of As(III) in water by graphite furnace atomic absorption spectrometry. Microchimica Acta 2008; 161: 137-142. doi:10.1007/s00604-007-0908-7

[20] Jung C, Heo J, Han J, Her N, Lee SJ et al. Hexavalent chromium removal by various adsorbents: Powdered activated carbon, chitosan, and single/multiwalled carbon nanotubes. Separation and Purification Technology 2013; 106: 6371.doi:10.1016/j.seppur.2012.12.028

[21] Werkneh A, Habtu NG, Beyene HD. Removal of hexavalent chromium from tannery wastewater using activated carbon primed from sugarcane bagasse: Adsorption/desorption studies.American Journal of Applied Chemistry 2014; 2:128-135. doi:10.11648/j.ajac.20140206.16

[22] Yang J, Yu M, Chen W. Adsorption of hexavalent chromium from aqueous solution by activated carbon prepared from longan seed: Kinetics, equilibrium and thermodynamics. Journal of Industrial and Engineering Chemistry 2015; 21: 414-422. doi:10.1016/j.jiec.2014.02.054

[23] Dedkova VP, Shvoeva OP, Savvin SB. Sorption-Spectrophotometric Determination of Zirconium and Chromium (VI) from a Single Sample on a Two-Layer Support Using Arsenazo III and 1,5-Diphenylcarbazide. Journal of Analytical Chemistry 2013; 68(2): 117-122. doi:10.1134/S1061934813020068

[24] Suryati L, Sulistyarti H, Atikah A. Development of spectrophotometric method for determination of chromium species using hypochlorite agent based on the formation of $\mathrm{Cr}(\mathrm{VI})$-Diphenylcarbazide complex. Journal of Pure and Applied Chemistry Research 2015; 4(1): 34-41.doi: 10.21776/ub.jpacr.2015.004.01.183

[25] Alvarado L, Ramírez A, Rodríguez-Torres I. $\mathrm{Cr}(\mathrm{VI})$ removal by continuous electrodeionization: Study of its basic technologies. Desalination 2009; 249(1): 423428. doi:10.1016/j.desal.2009.06.051. 
[26] Boclair JW, Braterman PS. Layered double hydroxide stability. 1. Relative stabilities of layered double hydroxides and their simple counterparts, Chemistry of Materials 1999; 11: 298-302. doi:10.1021/cm980523u

[27] Yan LG, Yang K, Shan RR, Yu HQ, Du B. Calcined $\mathrm{ZnAl}$ and $\mathrm{Fe}_{3} \mathrm{O}_{4} / \mathrm{ZnAl}$-layered double hydroxides for efficient removal of $\mathrm{Cr}(\mathrm{VI})$ from aqueous solution, RSC Advances 2005; 5: 96495-96503. doi:10.1039/c5ra17058c

[28] Ahmad MA, Puad NAA, Bello OS. Kinetic, equilibrium and thermodynamic studies of synthetic dye removal using pomegranate peel activated carbon prepared by microwave-induced $\mathrm{KOH}$ activation. Water Resources and Industry 2014; 6: 18-35. doi:10.1016/j.wri.2014.06.002

[29] Lazaridis NK, Asouhidou DD. Kinetics of sorptive removal of chromium (VI) from aqueous solutions by calcined $\mathrm{Mg}-\mathrm{Al}-\mathrm{CO}_{3}$ hydrotalcite. Water Research 2003; 37(12): 2875-2882. doi:10.1016/S00431354(03)00119-2

[30] Zhang B, Luan L, Gao R, Li F, Li Y et al. Rapid and effective removal of $\mathrm{Cr}(\mathrm{VI})$ from aqueous solution using exfoliated LDH nanosheets. Colloids and Surfaces A: Physicochemical and Engineering Aspects 2017; 520: 399-408. doi:10.1016/j.colsurfa.2017.01.074

[31] Fulazzaky MA, Khamidun MH, Omar R. Understanding of mass transfer resistance for the adsorption of solute onto porous material from the modified mass transfer factor models. Chemical Engineering Journal 2013;228: 1023-1029. doi:10.1016/j.cej.2013.05.100

[32] Karthikeyan G, Ilango SS. Adsorption of $\mathrm{Cr}(\mathrm{VI})$ onto activated carbons prepared from indigenous materials. E-Journal of Chemistry 2008; 5: 666678.doi:10.1155/2008/109398

[33] Doğan M, Abak H, Alkan M. Adsorption of methylene blue onto hazelnut shell : Kinetics, mechanism and activation parameters. Journal of Hazardous Materials 2009; 164: 172-181.doi:10.1016/j.jhazmat.2008.07.155
[34] Ghorbani-Khosrowshahi S, Behnajady MA. Chromium (VI) adsorption from aqueous solution by prepared biochar from OnopordomHeteracanthom. International Journal of Environmental Science and Technology 2016; 13(7): 1803-1814.doi:10.1007/s13762016-0978-3

[35] Ho YS. Removal of copper ions from aqueous solution by tree fern. Water Research 2003; 37(10): 2323-2330.doi:10.1016/S0043-1354(03)00002-2

[36] Prasad AL, Santhi T. Adsorption of hazardous cationic dyes from aqueous solution onto Acacia nilotica leaves as an eco-friendly adsorbent. Sustainable Environment Research 2012; 22(2): 113-122.

[37] Gorzin F, Abadi MBR. Adsorption of Cr (VI) from aqueous solution by adsorbent prepared from paper mill sludge: Kinetics and thermodynamics studies. Adsorption Science \& Technology 2017; 0(0): 1-21. doi:10.1177/0263617416686976

[38] Oguz E. Adsorption Characteristics and the Kinetics of the $\mathrm{Cr}(\mathrm{VI})$ on the ThujaOriantalis. Colloids and Surfaces A: Physicochemical and Engineering Aspects 2005; 252: 121-128.doi:10.1016/j.colsurfa.2004.10.004

[39] Romero-González J, Peralta-Videa JR, Rodríguez E, Ramirez SL, Gardea-Torresdey JL. Determination of thermodynamic parameters of $\mathrm{Cr}(\mathrm{VI})$ adsorption from aqueous solution onto Agave lechuguilla biomass. The Journal of Chemical Thermodynamics 2005; 37(4): 343-347. doi:10.1016/j.jct.2004.09.013

[40] Zhao D, Sheng G, Hu J, Chen C, Wang X. The adsorption of $\mathrm{Pb}(\mathrm{II})$ on $\mathrm{Mg}_{2} \mathrm{Al}$ layered double hydroxide. Chemical Engineering Journal 2011; 171: 167174. doi:10.1016/j.cej.2011.03.082

[41] Cantu Y, Remes A, Reyna A, Martinez D, Villarreal $\mathrm{J}$ et al. Thermodynamics, Kinetics, and Activation energy Studies of the sorption of chromium (III) and chromium (VI) to a $\mathrm{Mn}_{3} \mathrm{O}_{4}$ nanomaterial. Chemical Engineering Journal 2014; 254: 374383.doi:10.1016/j.cej.2014.05.110

[42] Aksu Z. Equilibrium and kinetic modelling of cadmium (II) biosorption by $C$. vulgaris in a batch 
system: effect of temperature. Separation and Purification Technology 2001; 21(3): 285-294.doi:10.1016/S13835866(00)00212-4

[43] Padmavathy V. Biosorption of nickel (II) ions by baker's yeast: Kinetic, thermodynamic and desorption studies. Bioresource Technology 2008; 99(8): 3100-3109. doi:10.1016/j.biortech.2007.05.070

[44] Giles CH, MacEwan TH, Nakhwa SN, Smith D. Studies in adsorption. Part XI. A system of classification of solution adsorption isotherms, and its use in diagnosis of adsorption mechanisms and in measurement of specific surface areas of solids. Journal of the Chemical Society 1960; (0): 3973-3993. doi:10.1039/JR9600003973

[45] Moosa AA, Ridha AM, Abdullha IN. Chromium Ions Removal from Wastewater Using Activated Iraqi Bentonite. International Journal of Innovative Research in Science, Engineering and Technology 2015; 4(2): 15-25. doi:10.15680/IJIRSET.2015.0402003

[46] Wang W, Zhou J, Achari G, Yu J, Cai W. $\mathrm{Cr}(\mathrm{VI})$ removal from aqueous solutions by hydrothermal synthetic layered double hydroxides: Adsorption performance, coexisting anions and regeneration studies. Colloids and Surfaces A: Physicochemical and Engineering Aspects 2014; 457: 33-40. doi:10.1016/j.colsurfa.2014.05.034

[47] Sevim AM, Hojiyev R, Gül A, Çelik MS. An investigation of the kinetics and thermodynamics of the adsorption of a cationic cobalt porphyrazine onto sepiolite. Dyes Pigments 2011; 88: 2538.doi:10.1016/j.dyepig.2010.04.011

[48] Zhang F, Hou W, Du N, Liang X. Sorption of $\mathrm{Cr}(\mathrm{VI})$ on $\mathrm{Mg}-\mathrm{Al}-\mathrm{Fe}$ Layered Double Hydroxides Synthesized By Mechanochemical Method. RSC Advances 2014; 4: 4682346830.doi:10.1039/C4RA07553F

[49] Jaiswal A, Mani R, Banerjee S, Gautam RK, Chattopadhyaya MC. Synthesis of novel nano-layered double hydroxide by urea hydrolysis method and their application in removal of chromium(VI) from aqueous solution: Kinetic, thermodynamic and equilibrium studies. Journal of Molecular Liquids 2015; 202: 5261.doi:10.1016/j.molliq.2014.12.004

[50] Alvarez R, Tóffolo A, Pérez V, Linares C. Synthesis and Characterization of CoMo/Zn-Al Mixed Oxide Catalysts for Hydrodesulphuration of Thiophene. Catalysis Letters 2010; 137: 150-155.doi:10.1007/s10562010-0337-9

[51] Malherbe F, Bigey L, Forano C, Roy A, Besse JP. Structural aspects and thermal properties of takovite-like layered double hydroxides pillared with chromium oxo-anions. Journal of the Chemical Society, Dalton Transactions 1999; 00: 38313839.doi:10.1039/a903766g

[52] Prasanna SV, Rao RAP, Kamath PV. Layered double hydroxides as potential chromate scavengers. Journal of Colloid and Interface Science 2006; 304: 292-299. doi:10.1016/j.jcis.2006.08.064

[53] Nakamoto K. Infrared and Raman Spectra of Inorganic and Coordination Compounds, New York: Wiley, 1963.

[54] El Malki K, Guenane M, Forano C, Roy A, Besse JP. Inorganic and Organic Anionic Pillars Intercalated in Lamellar Double Hydroxides. Materials Science Forum 1992; 91-93: 171176.doi:10.4028/www.scientific.net/MSF.91-93.171

[55] Newman SP, Jones W. Synthesis, characterization and applications of layered double hydroxides containing organic guests. New Journal of Chemistry 1998; 22(2): 105-115. doi:10.1039/A708319J

[56] Drits V, Sokolova T, Sokolova G, Cherkashin VI. New Members of the HydrotalciteManasseite Group. Clays and Clay Minerals 1987; 35: 401417.doi:10.1346/CCMN.1987.0350601

[57] Murthy V, Smith HD, Zhang H, Smith SC. Molecular Modeling of Hydrotalcite Structure Intercalated with Transition Metal Oxide Anions: $\mathrm{CrO}_{4}{ }^{2-}$ and $\mathrm{VO}_{4}{ }^{3-}$. The Journal of Physical Chemistry A 2011; 115(46): 13673-13683. doi:10.1021/jp2079499 
[58] Pan G, Xu M, Chen H, Tang P, Gao F, et al. Interlayer Structure and Ion-exchange Properties of Hydrotalcite Intercalated with $\mathrm{CO}_{3}{ }^{2-}, \mathrm{CrO}_{4}{ }^{2-}, \mathrm{SO}_{4}{ }^{2-}$ and $\mathrm{NO}_{3}{ }^{-}$. Advanced Materials Research 2011; 287-290: 21022105 . doi:10.4028/www.scientific.net/AMR.287290.2102

[59] Kumar N, Reddy L, Parashar V, Ngila JC. Controlled synthesis of microsheets of $\mathrm{ZnAl}$ layered double hydroxides hexagonal nanoplates for efficient removal of $\mathrm{Cr}(\mathrm{VI})$ ions and anionic dye from water. Journal of Environmental Chemical Engineering 2017; 5(2): 17181731.doi:10.1016/j.jece.2017.03.014

[60] Bourestan NR, Nematollahzadeh A, Jadid AP, Basharnavaz H. Chromium removal from water using granular ferric hydroxide adsorbents: An in-depth adsorption investigation and the optimization. Chemical Physics Letters 2020; 748: 137395.doi:10.1016/j.cplett.2020.137395

[61] Jalayeri H, Aprea P, Caputo D, Peluso A, Pepe F. Synthesis of amino-functionalized MIL-101(Cr) MOF for hexavalent chromium adsorption from aqueous solutions. Environmental Nanotechnology, Monitoring \& Management 2020; 14:

100300.doi:10.1016/j.enmm.2020.100300

[62] Chen Y, An D, Sun S, Gao J, Qian L. Reduction and Removal of Chromium VI in Water by Powdered Activated Carbon. Materials 2018; 11: 1-12. doi:10.3390/ma11020269

[63] Ajmani A, Patra C, Subbiah S, Narayanasamy S. Packed bed column studies of hexavalent chromium adsorption by zinc chloride activated carbon synthesized from Phanera vahlii fruit biomass. Journal of Environmental Chemical Engineering 2020; 8(4): 103825.doi:10.1016/j.jece.2020.103825

[64] Kumar Mondal N, Chakraborty S. Adsorption of $\mathrm{Cr}$ (VI) from aqueous solution on graphene oxide (GO) prepared from graphite: equilibrium, kinetic and thermodynamic studies. Applied Water Science 2020; 10: 61.doi:10.1007/s13201-020-1142-2
[65] Otgonjargal E, Nyamsuren B. Removal of Chromium from Aqueous Solution by Thermally Treated MgAl Layered Double Hydroxide. Annals of Civil and Environmental Engineering 2017; 1: 18.doi:10.29328/journal.acee.1001001

[66] Jiang X, Fan W, Li C, Wang Y, Bai J et al. Removal of $\mathrm{Cr}(\mathrm{VI})$ from wastewater by a two-step method of oxalic acid reduction-modified fly ash adsorption. RSC Advances 2019; 9: 33949-33956. doi:10.1039/c9ra05980f

[67] Kumari D, Mazumder P, Kumar M, Deka JP, Shim J. Simultaneous removal of Cong red and $\mathrm{Cr}(\mathrm{VI})$ in aqueous solution by using Mn powder extracted from battery waste solution. Groundwater for Sustainable Development 2018; 4: 459464.doi:10.1016/j.gsd.2018.01.001

[68] Liu H, Zhang F, Peng Z. Adsorption mechanism of $\mathrm{Cr}(\mathrm{VI})$ onto GO/PAMAMs composites. Scientific Reports 2019; 9: 3663. doi:10.1038/s41598-01940344-9

[69] Vu XH, Nguyen LH, Van HT, Nguyen DV, Nguyen TH, Nguyen QT, Ha LT. Adsorption of Chromium(VI) onto Freshwater Snail Shell-Derived Biosorbent from Aqueous Solutions: Equilibrium, Kinetics, and Thermodynamics. Journal of Chemistry 2019; 2019: 11 pages. doi:10.1155/2019/3038103

[70] Zhong L, He X, Qu J, Li X, Zhang Q, et al. Precursor preparation for $\mathrm{Ca}-\mathrm{Al}$ layered double hydroxide to remove hexavalent chromium coexisting with calcium and magnesium chlorides. Journal of Solid State Chemistry 2017; 245: 200-206.doi:10.1016/j.jssc.2016.10.022

[71] Islam MA, Angove MJ, Morton DW, Pramanik BK, Awual MR. A mechanistic approach of chromium (VI) adsorption onto manganese oxides and boehmite. Journal of Environmental Chemical Engineering 2020; 8(2): 103515. doi.org/10.1016/j.jece.2019.103515

[72] Islam MN, Khan MN, Mallik AK, Rahman MM. Preparation of bio-inspired trimethoxysilyl group terminated poly(1-vinylimidazole) modified-chitosan composite for adsorption of chromium (VI) ions. Journal 
of Hazardous Materials 2019; 379:

120792.doi:10.1016/j.jhazmat.2019.120792

[73] Kumar P, Chauhan MS. Adsorption of chromium (VI) from the synthetic aqueous solution using chemically modified dried water hyacinth roots. Journal of Environmental Chemical Engineering 2019; 7: 103218.doi:10.1016/j.jece.2019.103218 